\title{
The Influence of Task-based Language Teaching on Speaking Skill of EFL Students with Intrinsic Motivation
}

\author{
Afria Nita, Yenni Rozimela, Ratmanida \\ Faculty of Languages and Art, Universitas Negeri Padang, Padang, Indonesia \\ Email address: \\ afria.nita89@gmail.com (A. Nita),yennirozi@gmail.com (Y. Rozimela), ratmanida@gmail.com (Ratmanida)

\section{To cite this article:} \\ Afria Nita, Yenni Rozimela, Ratmanida. The Influence of Task-based Language Teaching on Speaking Skill of EFL Students with Intrinsic \\ Motivation. International Journal of Literature and Arts. Vol. 7, No. 6, 2019, pp. 179-184. doi: 10.11648/j.ijla.20190706.18
}

Received: November 14, 2019; Accepted: December 6, 2019; Published: December 18, 2019

\begin{abstract}
In teaching speaking, EFL students should be taught by a method that offers speaking practice and motivates them to speak intrinsically. Task-Based Language Teaching is one of teaching methods that uses authentic or real world tasks in teaching which can motivate students to speak English. This study aimed to investigate the influence of Task-Based Language Teaching on speaking skill of EFL students with intrinsic motivation. This study was a quantitative study which used quasiexperimental design. This study was conducted in one of Public Senior High School in Padang, West Sumatera, Indonesia. The sample involved one experimental and control class which consisted of 72 students which were chosen by cluster random sampling technique. The experimental class was taught by using Task-Based Language Teaching and the control class was taught by using Conventional Teaching. The data were collected through post test and questionnaire. The post test was used to find out the speaking skill of EFL students with intrinsic motivation and the questionnaire was used to determine the students' type of motivation. Then, the data were analyzed by using t-test formula with the significance alpha 0.05 . The result of the analysis indicated that the value of $\mathrm{t}_{\text {observed }}$ was 3.510 which was higher than the value of $\mathrm{t}_{\text {table }}$ that was 1.705 . Thus, it means that the EFL students with intrinsic motivation who were taught by using Task-Based Language Teaching had better speaking skill than those who were taught by using Conventional Teaching. In conclusion, Task-Based Language Teaching gave significant effect on speaking skill of EFL students with intrinsic motivation.
\end{abstract}

Keywords: Task-based Language Teaching, Speaking Skill, Students with Intrinsic Motivation

\section{Introduction}

Speaking is considered as the most fundamental skill in language learning. One's ability to communicate in a language is generally looked at how she or he can speak the language to express their opinions, thoughts and feelings [1]. In schools, speaking is often used as the measurement of the success of learners in learning English [2]. Thus, mastering speaking skill becomes important to achieve by the learners.

In high school current Indonesian curriculum (curriculum 2013), it is stated that the students should be able to create fluent and accurate spoken language in expressing meaning of short functional texts such as; descriptive, historical recount, narrative texts, etc. However, for Indonesian students, it is often difficult for some reasons. There are some students' problems in speaking, first the students have lack of speaking practice beyond classroom [3]. Second, the students need courage and preparation to speak [1]. Third, the students are worry to make mistakes, fearful of criticism, shy to speak and lack of vocabulary [4]. It can be concluded that the classroom learning should exposure speaking practices that encourage learners to speak freely without feeling worry, fearful, shy and the other factors that may distract them to speak.

To achieve the success of learning foreign language, an appropriate teaching method is very important [5]. In this case, the teacher should select a method that facilitates the students to achieve the learning goals and provide speaking practice. Besides, it should also engage the students to speak. Hence, it does not only facilitate the students to practice speaking, but also engage them to speak using English.

Task-Based Language Teaching (TBLT) is considered as one of teaching method that can facilitate students to speak by using English. It emphasizes the use of English in task accomplishment. It involves real communication and promote learning [6]. In accomplishing task, the students are 
asked to negotiate meaning which involves discussion activity. Furthermore, the authentic or real world task is one of communicative task that can engage and motivate the students to speak by using target language. By giving authentic or real world task, the students get meaningful communication related to their real world, hence they are more motivated to involve in the learning process. Thus, it is assumed that TBLT gives opportunity for students to practice their English during accomplishing communicative tasks.

In line with above opinions, TBLT can intrinsically motivate students to speak as the students are given opportunity to speak English without worrying failures of accuracy [7]. They are allowed to speak freely without explicit grammar correction from the teacher, hence the students have a courage to speak English. Motivation is one of the factors of the students' success in learning English [8]. Further, there are some researchers that found relatedness between motivation, task and speaking. It was found that the students who have intrinsic motivation tend to be motivated in accomplishing task [9] and have more engagement to complete the learning task and put more effort to understand the task content [10]. Automatically, having motivation in accomplishing task means that the students do more effort to get the outcome of the task itself which is the students will do more effort to speak English.

Currently, some studies about Task-Based Language Teaching and speaking have been conducted by some researchers. The results indicated that Task-Based Language Teaching gave significant effect on speaking improvement. Task-Based Language Teaching provides opportunity for students to practice speaking with partners, thus they have more confidence and less anxiety to speak [11, 12]. Additionally, Task-Based Language Teaching could improve the students' communicative competence [13] and speaking fluency since their grammar was not corrected explicitly and they would be more active to speak when they were given the authentic or real world tasks [14]. However, the grammatical accuracy could not be ignored. In the implementation of Task-Based Language Teaching, corrective feedback strategies like recasts is appropriate to be applied without inhibit the students' fluency. From these findings, it can be concluded that the implementation of Task-Based Language Teaching gives a positive effect on speaking skill of EFL students with intrinsic motivation.

Yet, even though some researchers had conducted the study about Task-Based Language Teaching and speaking, this research is still needed in Indonesia since the study that investigates the influence of Task-Based Language Teaching on intrinsic motivated students' speaking skill is still limited. Thus, this research investigates the influence of Task-Based Language Teaching on speaking skill of EFL students with intrinsic motivation.

\section{Task-based Language Teaching}

Task-Based Language Teaching is an approach or method that uses task as learning instruction [6]. The task given should be meaningful and authentic. Meaningful means that the task is useful for students while authentic means that the task is related to the students' real world situation. Task is divided into real world task and pedagogical task $[6,15]$. Real world task is a task that related and useful in the real world, while pedagogical task is a task or activity that carried out as the result of understanding language.

There are three stages of Task-Based Language Teaching involving pre-task, task cycle and language focus [16]. Pretask includes introduction to the topic and task. Introducing the topic can be done by brainstorming the students knowledge through picture, video, etc. While introducing the task means that the teacher models and explains how to do the task.

The second phase is task-cycle. The task phase allows the students to show effort to complete the task. This phase allows the students to communicate and carry out in the meaningful activity that focuses on fluency. This phase involves three components of task cycle; task, planning and report [16].

The third phase is language focus. This phase involves two components of language focus; language analysis and language practice [16]. In language analysis, the teacher sets some language-focused task to identify some features of language, for example; finding words or phrases related to the topic, or finding the verb in simple past form. In language practice, the students practice the language features that had been identified, for example; sentence completion, matching past verbs, etc.

\section{Speaking Skill}

Speaking is a productive skill which is used to convey meaning. It is the active use of language to express meaning [17]. Similarly, it is defined as a productive skill that consists of producing systematic verbal utterances to convey meaning [18]. Thus, speaking is a productive process of language including conveying meaning, ideas or informations. Beside expressing meaning, speaking involves the students' ability to convey contextual meaning fluently, accurately and communicatively.

The purpose of teaching speaking is to develop students' ability on communicative ability. The objective of teaching speaking is to develop the students' ability in interaction using that language which involve comprehension and production [19].

Furthermore, the purpose of speaking is to develop students' communicative competence [20]. He divides it into grammatical, discourse, sociolinguistic and strategic competence. Grammatical competence means the competence of linguistic code of language, such as; lexical, morphology, syntax, semantic and phonology. Discourse competence means the competence to connect discourse and form of whole utterances. Sociolinguistic competence means the competence of understanding social context, role of participants, information and speaking function. And strategic competence refers to the strategies that one uses to 
compensate for imperfect rules, repair and avoid mistakes and guessing meaning from the context.

Speaking of genre or text type is very important to be mastered. It is stated in 2013 curriculum that the students are demanded to be able to produce spoken and written form of genre. For the ten grade students of Senior High School, the texts that are taught are descriptive, recount and narrative. In this research, the historical recount and narrative texts are taught by the researcher.

Historical recount is one type of recount text. It tells about history that happened in the past. The generic structure is same with the recount text, there are orientation, sequence of events and reorientation. The purpose of historical recount text is to tell or explain the reader about the sequence of events in a history. The example of historical recount are the history of battle of Surabaya, Bandung as sea of fire, Rengasdengklok, etc.

While, narrative text is a kind of text that telling about the story in the past and the purpose is to amuse reader. There are some steps of constructing narrative text; orientation, complication and resolution. There are some types of narrative text such as; legend, fairy tale, fable, science fiction story, romantic story, humorous story, thriller, folk tale, etc. In this research, the researcher chose narrative legend as the topic.

\section{Motivation}

To be motivated means to be moved to do something [21]. A person who feels no impetus and inspiration to act is characterized as unmotivated person, whereas someone who energized or activated to do something is considered as motivated person. In other words, a motivated person shows spirit and enthusiastic to do something.

According to self-determination theory, there are two general types of motivation; intrinsic and extrinsic motivation [22, 21]. Intrinsic motivation refers to the students' motivation to engage in activity because that activity is enjoyable and satisfying to do. In this case, the students do something for their own interest. While, extrinsic motivation refers to doing something because it leads to a separable outcome, such as; earning a reward or avoiding punishment, gaining success, etc. This extrinsic motivation can be derived from teacher, parents and other external factors.

Indicators of intrinsic motivation are divided into effort, desire and attitude [23]. Such in speaking skill, effort refers to the students' persistence to practice speaking in the classroom. Desire refers to the students' wants to practice English for specific goals. Attitude refers to the students' feeling or behavior when practicing speaking.

While indicators of extrinsic motivation are divided into; external, introjected and identified regulation [21]. External regulation are performed to satisfy an external demand or obtain externally imposed reward contingency. Introjected regulation describes people to do something in order to avoid guilt or anxiety, attain ego-enhancements or pride. And identified regulation describes the people do something because the value is useful and related to their goals.

\section{Method}

This study employed quasi-experimental design. The population of the research was the ten grade students of one of Public Senior High School in Padang, West Sumatera, Indonesia. The number of population was eight classes which consist of 287 students. Two classes of the ten grade students were selected randomly as the sample which involve experimental and control class. The experimental class was taught by using Task-Based Language Teaching and the control class was taught by using Conventional Teaching.

Speaking test and questionnaire were used as the instrument of this research. The speaking test was used to find out students' speaking skill and the questionnaire was used to find out the the type of students' motivation whether they are intrinsic or extrinsic motivated students. The test consisted of two kinds; monologue and dialogue. The monolog test was used to assess the students' speaking skill of Historical Recount text while dialog test was used to assess speaking skill of Narrative Text. For monologue test, the students were given several topics of Historical Recount that must be presented in front of the class. In the dialogue test, the students were required to create a dialogue based on one topic of narrative text that they chose among several topics provided.

To test validity and reliability of the test, the researcher used content validity and inter-rater reliability. The content of the test must be related to the syllabus. The test was consulted to the validator who was expert on it. To test the reliability of the test, the researcher used inter-rater reliability in scoring the test. There were two scorers involved the researcher and one of English teacher. The final score were accumulated from the total score of two scorers. Then, to test validity and reliability of the questionnaire, it was consulted to the validator and it was analyzed by using product moment formula. For reliability of the questionnaire, the researcher used Cronbach's Alpha formula to analyze the questionnaire. After testing validity and reliability, the questionnaire was tried out to respondent class. At last, the questionnaire was distributed to experimental and control class before treatment in order to find the students' type of motivation.

\section{Results and Discussion}

\subsection{Results}

The findings of this research deal with speaking score of EFL students with intrinsic motivation in experimental and control class. To determine the students who have intrinsic motivation, the researcher analyzed the score of students' questionnaire by investigating the higher score between intrinsic and extrinsic score. After analyzing the data, the maximum score of students' speaking score in experimental 
class was 94 and the minimum score was 82 . The mean score was 87.75 , the standard deviation was 3.41 and the variance was 11.66. While, the maximum score of students' speaking score in control class was 92 and the minimum score was 74 . The mean score was 81.83 , the standard deviation was 5.49 and the variance was 30.15 . Based on analysis, it was found that the speaking score for intrinsic motivation students in experimental class was higher than the mean score of students' speaking in control class. The description can be seen in the following table:

Table 1. The Summary of Speaking Score for Students with Intrinsic Motivation in Experimental and Control Class.

\begin{tabular}{lllllll}
\hline Class & N & Mean & Max & Min & SD & Sum \\
\hline Experiment & 16 & 87.75 & 94 & 82 & 3.41 & 1404 \\
Control & 12 & 81.83 & 92 & 74 & 5.49 & 982 \\
\hline
\end{tabular}

The table above shows that the students who have intrinsic motivation who are taught by using Task-Based Language Teaching had better speaking skill than the students who have intrinsic motivation who are taught by using Conventional Teaching.

The normality and homogeneity testing were tested. Then, the hypothesis was tested by using t-test formula. The detail description can be seen on the following explanation.

i. Normality Testing

The normality testing was used to find out whether the data in experimental and control class are normally distributed or not. After analyzing, the significance value was 0.132 in experimental class and 0.809 in control class. The normality of speaking score for students with intrinsic motivation in experimental and control class can be seen below:

Table 2. The Summary of Normality Testing of Speaking Skill for Students with Intrinsic Motivation in Experimental and Control Class.

\begin{tabular}{lllll}
\hline Class & N & Sig.(2-tailed) & Sig. Alpha & Conclusion \\
\hline Experiment & 16 & 0.132 & 0.05 & Normal \\
Class & 12 & 0.089 & 0.05 & Normal \\
\hline
\end{tabular}

The table above shows that the data of speaking skill for students with intrinsic motivation in experimental and control class were normally distributed because the significance value in both classes was higher than significance alpha 0.05 . The significance value of experimental class was 0.132 which was higher than significance alpha 0.05 . It is similar with the control class where the significance value was 0.809, which was higher than significance alpha 0.05 .

ii. Homogeneity Testing

The homogeneity testing is used to find out whteher the data in experimental and control class were are homogeny or not. After analyzing, the significance value was 0.122 . The homogeneity of speaking score for intrinsic motivation students in experimental and control class can be seen below:
Table 3. The Summary of Homogeneity Testing of Speaking Skill for Students with Intrinsic Motivation in Experimental and Control Class.

\begin{tabular}{llllll}
\hline Test of Homogeneity of Variance & Levene Statistic & df1 & df2 & Sig. \\
\hline \multirow{4}{*}{ Score } & Based on Mean & 2.555 & 1 & 26 & .122 \\
& $\begin{array}{l}\text { Based on Median } \\
\text { Based on Median and } \\
\text { with adjusted df }\end{array}$ & 2.480 & 1 & 26 & .127 \\
& Based on trimmed mean & 2.480 & 1 & 22.455 & .129 \\
\hline
\end{tabular}

The table above indicates that the data of speaking skill for students with intrinsic motivation in experimental and control class were homogeneous. The data are homogenous if significance value is higher than significance alpha 0.05 . From the table, the significance value is 0.122 which is higher than significance alpha 0.05 .

iii. Hypothesis Testing

In this study, the hypothesis can be seen as follows:

$\mathrm{H}_{0}$ : Task-Based Language Teaching does not give higher result on speaking skill for intrinsic motivation students than Conventional Teaching

$\mathrm{H}_{1}$ : Task-Based Language Teaching gives higher result on speaking skill for intrinsic motivation students than Conventional Teaching

In analyzing the hypothesis, the data was calculated by using Independent sample t-test which the value of $t_{\text {observed }}$ was compared to the value of $t_{\text {table. }}$ Ha is accepted if the value of $t_{\text {observed }}$ is higher than $t_{\text {table }}$ and Ha is rejected if the value of

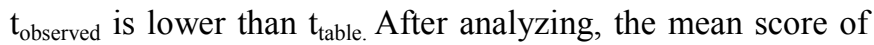
speaking score of intrinsic motivation students in experimental was 87.75 which was higher than control class which the mean score was 81.83 . Then, the $t_{\text {observed }}$ was 3.510 which was higher than $t_{\text {table }}$ that was 1.705 . The statistical analysis of speaking skill for intrinsic motivation students in experimental and control class can be seen in the following table:

Table 4. The Summary of T-test Analysis of Speaking Skill for Students with Intrinsic Motivation in Experimental and Control Class.

\begin{tabular}{lllllll}
\hline Class & $\mathbf{N}$ & Mean & SD & $\mathbf{t}_{\text {observed }}$ & $\mathbf{t}_{\text {table }}$ & Conclusion \\
\hline Experiment & 16 & 87.75 & 3.41 & \multirow{2}{*}{3.510} & \multirow{2}{*}{1.705} & $\begin{array}{l}\mathrm{t}_{\text {observed }}>\mathrm{t}_{\text {table }} \mathrm{Ha} \\
\text { Control }\end{array}$ \\
12 & 81.83 & 5.49 & & & accepted \\
\hline
\end{tabular}

The result of hypothesis indicates that the value of $t_{\text {observed }}$ is 3.510 which was higher than the value of $t_{\text {table }} 1.705$. It means that the alternative hypothesis $(\mathrm{Ha})$ is accepted and the null hypothesis is rejected. Thus, the students with intrinsic motivation who are taught by using Task-Based Language Teaching have better speaking skill than those who are taught by using Conventional Teaching.

Based on the findings which were gotten from data analysis of the students' speaking test, the hypothesis indicates that Task-Based Language Teaching gives a positive effect on speaking skill for students with intrinsic motivation than Conventional Teaching. It means that TaskBased Language Teaching is effective to improve speaking skill of EFL students with intrinsic motivation. 


\subsection{Discussion}

The result of this study shows that there was a significant effect of TBLT on speaking skill for EFL students with intrinsic motivation. It can be seen from the mean score and t-test of speaking skill in both experimental and control class. The mean score of students' speaking skill in experimental class was 87.75 and 81.83 in control class. The value of t-test in experimental class was 3.510 and 1.705 in control class. Thus, it shows that the mean score and t-test of students' speaking skill in experimental class are higher than control class. Thus, it can be concluded that the students with intrinsic motivation who were taught by Task-Based Language Teaching have better speaking skill compared with the students who were taught by Conventional Teaching.

Dealing with this result, it is important to know the relation among Task-Based Language Teaching, motivation and speaking. Those are all interrelated. The use of authentic task or task that related to the students' real world can improve motivation and promote learning [6]. It can be said that Task-Based Language Teaching can enhance motivation. On the other hand, it was found that intrinsic motivation helps the students to achieve better speaking proficiency [24]. It was also found that the authentic or real world tasks can intrinsically motivate students to accomplish the task and hence increase speaking skill [25].

Furthermore, interesting task can motivate the students to accomplish the task intrinsically. The interesting task can be gained through the activities of task. For example, the students are asked to make a fishbone diagram to describe the sequence of historical event. In doing this task, the students were more motivated to do the task because they like to describe the sequence of event through creating a diagram. Automatically, they also were more motivated to speak if they have enthusiastic in doing the task.

Moreover, the exposure of speaking practice in classroom can motivate the students to follow the learning process. In Task-Based Language Teaching, the students were asked to plan their report draft before they presented the result of discussion. In this stage, the students rehearsed what they want to say. They might do peer correction of grammar, vocabulary, etc within their group. The rehearsal activities could motivate them to speak because it decreases anxiety.

From the stages of Task-Based Language Teaching, the students also engage to the activities in each stage. In pretask stage, the teacher did brainstorming activity by showing pictures and videos. This stage allowed the students to think critically and express their opinions toward the pictures and videos. This activity helps the students to think several ideas or informations that related to the topic in order they can express their opinion easily. Additionally, this stage trigerred the students to related vocabulary, grammar, pronunciation, etc [25]. It is because in pre-task stage, the teacher discusses the difficult vocabularies or phrases that are related to the topic. Thus, the students can discuss the task in their group easily.

In task-cycle, the students did discussion in pair or group to complete their task and achieve the goals of the tasks. In this stage, the group prepared the task report and practiced each other. In this stage, the students practice their critical thinking related to the topic. This activity gave the students chance to decrease their communicative pressure, increase their confident and at last increase their speaking ability [25]. This also helped the students to identify the speaking strategies that they can use in report stage. The represented group presented their result of the task in front of the class and the other groups compared their result. From this activity, the students can get new knowledge through comparing and discussing the other group result, such as grammar pattern, words, phrases, etc.

In language focus, the students were asked to analyze the correctness of grammar used in the previous stages. Then, the students were asked to practice by producing language by using correct grammar. This activities were very useful for students to improve their grammar implicitly. It means that in Task-Based Language Teaching, the teacher allows students to speak without correcting grammar while they are speaking. It also can improve students' grammar since this stage emphasizes the use of correct language features.

From those three stages of Task-Based Language Teaching, the researcher can conclude that Task-Based Language Teaching gives chance for students to express their opinions, practice their speaking in group and learn grammar implicitly. So, the students were not afraid to speak because their grammar were not corrected explicitly. However, the grammar was analyzed in the last stage of learning process.

In conclusion, the EFL students with intrinsic motivation who were taught by Task-Based Language Teaching had better speaking skill than those who were taught by Conventional Teaching. It is because the use of authentic and interesting task can motivate the students to speak intrinsically. Also, the exposure of speaking practice can engage the students to speak.

\section{Conclusion}

Based on the findings and discussion, it can be concluded that the EFL students with intrinsic motivation who are taught by using Task-Based Language Teaching have better speaking skill than those who are taught by using Conventional Teaching. It means that Task-Based Language Teaching is effective to be implemented in teaching speaking. Task-Based Language Teaching helps the students to practice their speaking through accomplishing the authentic or real world tasks. The tasks or activities are meaningful for students in their real life, so it makes them interested to speak English in the classroom.

\section{References}

[1] Malihah, N. (2010). "The Effectiveness of Speaking Instruction through Task-Based Language Teaching". REGISTER. Vol 3, No 1. 
[2] Richards, J. C. (2008). Teaching Listening and Speaking From Theory to Practice. New York: Cambridge University Press.

[3] Aleksandrzak, M. (2011). "Problems and Challenges in Teaching and Learning Speaking at Advanced Level”. 2011. Uniwersytet im Adama Mickiewicza w Poznaniu.

[4] Ur, P. (1996). A Course in Language Teaching: Practice and Theory. New York: Cambridge University Press.

[5] Zhou, Y. (2016). “Applying Task-based Language Teaching in Introductory-level Mandarin Language Classes at the College of the Bahamas". The International Journal of Bahamian Studies, 22, p. 34-42.

[6] Richards, J. C. and Theodore, S. R. (2001). Approaches and Methods in Language Teaching (Second Edition). UK: Cambridge University Press.

[7] Willis, D. and Jane, W. (2007). Doing Task-Based Teaching. New York: Oxford University Press.

[8] Brown, H. D. 2002. Strategies for Success: A Practical Guide to Learning English. New York. Longman.

[9] Appel, C. \& Roger, G. (2002). "Motivation and Task Performance in a Task-based Web-based Tandem Project". Cambridge Journal ReCALL, Vol. 4, Issue. 1, p. 16-31.

[10] Saeed, S. and David, Z. (2012). "How Motivation Influences Student Engagement: A Qualitative Case Study". Journal of Education and Learning, Vol. 1, No. 2, p. 252-267.

[11] Ho, P. V. P and Nguyen, H. L. (2014). “The Impacts of TaskBased Speaking Activities on English Majored Freshmen's Oral Performance at Ba-Ria Vung Tau Teacher Training College". Journal of Science Ho Chi Minh City Open University, No 3 (11), p. 71-82.

[12] Anjum, et.al. (2019). "The Effect of Task-Based Language Learning (TBLL) on Developing Speaking Skills of Secondary School Learners in Pakistan". 2019. International Journal of Lingustics, Vol. 9, No. 2, p. 283-291.

[13] Carolina, A. (2016). Improving 10th Graders' English
Communicative Competence through the Implementation of the Task-based Learning Approach. Profile Issues in Teachers' Professional Development, 18 (2): 95-100.

[14] Albino, G. (2017) "Improving Speaking Fluency in a Taskbased Language Teaching Approach: The Case of EFL Learners at PUNIV-Cazenga". SAGE Open. p. 1-1.

[15] Nunan, D. (2004). Task-based Language Teaching. New York: University Press.

[16] Willis, J. (1996). A Framework for Task-based Learning. Edinburgh: Addison Wesley Longman Limited.

[17] Cameron, D. 2001. Working with Spoken Discourse. Oxford: SAGE Publications, Ltd.

[18] Nunan, D. (2003). Practical English Language Teaching (First edition). New York: Mc. Graw Hill.

[19] Hughes, A. (2003). Testing for Language Teachers (Second Edition). UK: Cambridge University Press.

[20] Brown, H. D. (2007) Principles of Language Learning and Teaching (Fifth Edition). New York: Pearson Education.

[21] Ryan, R. M and Edward. L. D. 2000. "Intrinsic and Extrinsic Motivations: Classic Definitions and New Directions". Contemporary Educational Psychology 25, p. 54-67.

[22] Noels, K. A, et.al. 2000. "Why Are You Learning A Second Language? Motivational Orientations and Self-Determination Theory". Language Learning 50: 1, p. 57-85.

[23] Ihsan, M. D. 2016. "Students' Motivation in Speaking English". Journal of English Educators Society (JEES), Vol. 1, p. 31-48.

[24] Wilona, et.al. (2010). "The Correlation Between Intrinsic Motivation and Speaking Proficiency of The English Department Students". Magister Scientiae, No. 27, p. 45-56.

[25] Mohammadipour, et.al. (2018). "The Relationships between Language Learning Strategies and Positive Emotions among Malaysian ESL Undergraduates". International Journal of Education and Literacy Studies, Vol. 6, Issues 1, p. 89-96. 